\title{
Are We Doing it For the Money? A Salary Survey of the United States Surgical Program Directors
}

\author{
Alexander Hoey, BA \\ Thomas Jefferson University \\ Brian Hoey, MD \\ St. Luke's University Health Network \\ Stanislaw Stawicki, MD \\ St. Luke's University Health Network
}

Follow this and additional works at: https://jdc.jefferson.edu/si_ctr_2021_phase1

Part of the Surgery Commons

\section{Let us know how access to this document benefits you}

\section{Recommended Citation}

Hoey, Alexander; Hoey, Brian; and Stawicki, Stanislaw; "Are We Doing it For the Money? A Salary Survey of the United States Surgical Program Directors" (2019). SKMC JeffMD Scholarly Inquiry, Phase 1, Project 1.

This Article is brought to you for free and open access by the Jefferson Digital Commons. The Jefferson Digital Commons is a service of Thomas Jefferson University's Center for Teaching and Learning (CTL). The Commons is a showcase for Jefferson books and journals, peer-reviewed scholarly publications, unique historical collections from the University archives, and teaching tools. The Jefferson Digital Commons allows researchers and interested readers anywhere in the world to learn about and keep up to date with Jefferson scholarship. This article has been accepted for inclusion in Phase 1 by an authorized administrator of the Jefferson Digital Commons. For more information, please contact: JeffersonDigitalCommons@jefferson.edu. 
Alexander Hoey

SKMC Class of 2021

SI CTR Abstract

$12 / 15 / 18$

\section{Are We Doing it For the Money? A Salary Survey of the United States Surgical Program Directors}

Alexander Hoey, BA; Dr. Brian Hoey, MD; Stanislaw Stawicki, MD

Compensation packages and job responsibilities for United States surgical program directors

(PD) vary considerably from one institution to the next. ${ }^{1} \mathrm{With}$ limited compensation data

available for PD's, this survey reassesses and compares the salaries, benefits, duties, and contract

arrangements of all allopathic U.S. surgical PDs. Questionnaires regarding these areas of interest were mailed out electronically to all of the PDs and data was compared between the individuals' responses using Chi-Squared and Fischer Exact Tests. Fifty-five percent of the PDs responded, revealing significant variation in total compensation packages, size of the dedicated stipend for the role, and time spent on clinical and administrative tasks. Mean salary reported by the group was $\$ 340,000$ and nearly one-third of the directors reported they were dissatisfied with their current compensation package. These survey results reveal a continued incongruency in the responsibilities and pay of surgical PDs across the country. Furthermore, the information gathered could be utilized to set a compensation standard for PDs and their employers in future contract negotiations.

1. ${ }^{1}$ Hoey, B. A., Stehly, C. D., Lukaszczyk, J. J., Riley, L., Stoltzfus, J., \& Dattilo, J. B. (2008). Are we doing it for the money? A salary survey of United States surgical program directors. Journal of surgical education, 65(6), 401-405. 